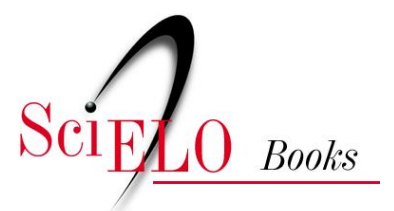

\title{
Nova fase da luta
}

\author{
Euclides da Cunha
}

\section{SciELO Books / SciELO Livros / SciELO Libros}

CUNHA, E. Nova fase da luta. In: Os sertões [online]. Rio de Janeiro: Centro Edelstein de Pesquisas Sociais, 2010. pp. 429-461. ISBN: 978-85-7982-007-6. https://doi.org/10.7476/9788579820076.0008.

\section{(8) Poviuci}

This work is free of known copyright restrictions. http://creativecommons.org/publicdomain/mark/1.0/

Este trabalho está livre de restrições de direito de autor e/ou de direitos conexos conhecidas.

http://creativecommons.org/publicdomain/mark/1.0/

Esta obra está libre de restricciones conocidas de derechos autorales. http://creativecommons.org/publicdomain/mark/1.0/ 


\section{NOVA FASE DA LUTA}

I. Queimadas. Uma ficção geográfica. Fora da pátria. Diante de uma criança. Na estrada de Monte Santo. Novas animadoras. Uma vaia entusiástica... Trincheira Sete de Setembro. Estrada de Calumbi.

II. Marcha da divisão auxiliar. Medo glorioso. Aspecto do acampamento. Em busca de uma meia ração de glória. O charlatanismo da coragem.

III. Embaixada ao céu. Complemento do assédio. 


\section{Capítulo I}

\section{Queimadas}

Queimadas, povoado desde o começo deste século, mas em plena decadência, fez-se um acampamento ruidoso $\mathrm{O}$ casario pobre, desajeitadamente arrumado aos lados da praça irregular, fundamente arado pelos enxurros - um claro no matagal bravio que o rodeia - e, principalmente, a monotonia das chapadas que se desatam em volta, entre os morros desnudos, dão-lhe um ar tristonho completando-lhe o aspecto de vilarejo morto, em franco descambar para tapera em ruínas.

Prendiam-se-lhe, ademais, recordações penosas. Ali tinham parado todas as forças anteriormente envolvidas na luta, no mesmo prolongamento do largo aberto para a caatinga cujos tons pardos e brancacentos, de folhas requeimadas, sugeriam a denominação da vila. Acervos repugnantes de farrapos e molambos; trapos multicores e imundos, de fardamentos velhos; botinas e coturnos acalcanhados; quepes e bonés; cantis estrondados; todos os rebotalhos de caserna, esparsos em área extensa, em que branqueavam restos de fogueiras, delatavam a passagem dos lutadores, que lá armaram as tendas, a partir da expedição Febrônio. Naquele chão batido dos rastros de 10 mil homens, haviam turbilhonado na vozeria dos bivaques - paixões, ansiedades, esperanças, desalentos indescritíveis.

\section{Páginas demoníacas}

Transposta acessível ondulação, via-se, recortando o cerrado dos arbustos, um sulco largo de roçada, retilíneo e longo, que um alvo extremava - a linha de tiro, onde se exercitara a divisão Artur Oscar. Perto, ao lado, a capela exígua e baixa, como um barracão murado. E nas suas paredes, cabriolando doidamente, a caligrafia manca e a literatura bronca do soldado. Todos os batalhões haviam colaborado nas mesmas páginas, escarificando-as a ponta de sabre ou tisnando-as a carvão, no gravarem as impressões do momento. Eram páginas demoníacas aqueles muros sacrossantos: períodos curtos, incisivos, arrepiadores; blasfêmias fulminantes; imprecações, e brados, e vivas calorosos, rajavam-nas em todo o sentido, profanando-as, mascarando-as, em caracteres negros espetados em pontos de admiração, compridos como lanças.

Dali para baixo, no descair de insensível descida, uma vereda estreita e mal afamada - a estrada de Monte Santo, por onde tinham abalado, esperançosas, três expedições sucessivas, e de onde chegavam, agora, sucessivamente, bandos miserandos de foragidos. Vadeado o Jacurici, volvendo águas rasas e mansas, ela enfiava, inflexa, pelas chapadas fora, ladeada, em começo, por uma outra que demarcavam os postes da linha telegráfica recentemente estabelecida.

\section{Uma ficção geográfica}

A linha férrea corre no lado oposto. Aquele liame do progresso passa, porém, por ali, inútil, sem atenuar sequer o caráter genuinamente roceiro do arraial. Salta-se do trem; transpõe-se poucas centenas de metros entre casas deprimidas; e topa-se para logo, à fímbria da praça — o sertão...

Está-se no ponto de tangência de duas sociedades, de todo alheias uma à outra. $\mathrm{O}$ vaqueiro encourado emerge da caatinga, rompe entre a casaria desgraciosa, e estaca o campião junto aos trilhos, em que passam, vertiginosamente, os patrícios do litoral, que o não conhecem.

\section{Fora da pátria}

Os novos expedicionários ao atingirem-no perceberam esta transição violenta. Discordância absoluta e radical entre as cidades da costa e as malocas de telha do interior, que desequilibra tanto o ritmo de nosso desenvolvimento evolutivo e perturba a unidade nacional. Viam-se em terra estranha. Outros hábitos. Outros quadros. Outra gente. Outra língua mesmo, articulada em gíria original e pinturesca. Invadia-os o sentimento exato de seguirem para uma guerra externa. Sentiam-se fora do Brasil. A separação social completa dilatava a distância geográfica; criava a sensação nostálgica de longo afastamento da pátria.

Além disto, a missão que ali os conduzia frisava, mais fundo, o antagonismo. O inimigo lá estava, para leste e para o norte, homiziado nos sem-fins das chapadas, e no extremo delas, ao longe, se desenrolava um drama formidável... 
Convinha-se em que era terrivelmente paradoxal uma pátria que os filhos procuravam armados até os dentes, em som de guerra, despedaçando as suas entranhas a disparos de Krupps, desconhecendo-a de todo, nunca a tendo visto, surpreendidos ante a própria forma da terra árida, e revolta, e brutal, esvurmando espinheiros, tumultuando em pedregais, esboroando em montanhas derruídas, escanceladas em grotões, ondeando em tabuleiros secos, estirando-se em planuras nuas, de estepes...

$\mathrm{O}$ que ia fazer-se era o que haviam feito as tropas anteriores - uma invasão - em território estrangeiro. Tudo aquilo era uma ficção geográfica. A realidade, tangível, enquadrada por todos os sucessos, ressaltando à observação mais simples, era aquela. Os novos campeadores sentiam-na dominadoramente. E como aquele povo desconhecido de matutos lhes devolvia, dia a dia, mutilados e abatidos, os companheiros que meses antes tinham avançado robustos e altaneiros, não havia ânimo varonil que atentasse impassível para as bandas do sertão misterioso e agro...

\section{Em Canudos}

Felizmente tiveram ao chegar o contrachoque de notícias animadoras recém-vindas do campo de operações.

Nenhum outro desastre ocorrera. Guardavam-se, malgrado tiroteios diários, as posições conquistadas. A Brigada Girard e o Batalhão Paulista tinham ido a tempo de preencher os claros da linha rarefeita do sítio. Com este reforço coincidiam os primeiros sintomas de desânimo entre os rebeldes: não batia mais com a sua serenidade gloriosa o sino da igreja velha, que caíra; não mais se ouviam ladainhas melancólicas entre os intervalos das fuzilarias; cessavam os ataques atrevidos às linhas; e à noite, sem o bruxulear de uma luz, o arraial mergulhava silenciosamente nas sombras. Reproduzia-se a atoarda de que o Conselheiro lá estava, agora, coacto, preso pelos próprios sequazes, revoltados pelo intento, que manifestara, de se entregar, dispondo-se ao martírio.

E citavam-se pormenores incidindo todos no denunciar o afrouxamento rápido da conflagração.

\section{Prisioneiros}

Os novos combatentes imaginaram-na extinta antes de chegarem a Canudos. Tudo o indicava. Por fim os próprios prisioneiros que chegavam, e eram, no fim de tantos meses de guerra, os primeiros que apareciam. Notou-se apenas, sem que se explicasse a singularidade, que entre eles não surgia um único homem feito. Os vencidos, varonilmente ladeados de escoltas, eram fragílimos: meia dúzia de mulheres tendo ao colo crianças engelhadas como fetos, seguidas dos filhos maiores, de seis a dez anos. Passavam pelo arraial, entre compactas alas de curiosos em que se apertavam fardas de todas as armas e de todas as patentes. Um espetáculo triste.

As infelizes, em andrajos, camisas entre cujas tiras esfiapadas se repastavam olhares insaciáveis, entraram pelo largo, mal conduzindo pelo braço os filhos pequeninos, arrastados.

Eram como animais raros num divertimento de feira.

Em volta cruzavam-se, em todos os tons, comentários de toda a sorte, num burburinho de vozes golpeadas de interjeições vivíssimas, de espanto. O agrupamento miserando foi por algum tempo um derivativo, uma variante feliz aligeirando as horas enfadonhas do acampamento.

Mas acirrou a curiosidade geral, sem abalar os corações.

\section{Diante de uma criança}

Um dos pequenos - franzino e cambaleante - trazia à cabeça, ocultando-a inteiramente, porque descia até aos ombros, um velho quepe reúno, apanhado no caminho. O quepe largo e grande demais, oscilava grotescamente, a cada passo, sobre o busto esmirrado que ele encobria por um terço. E alguns espectadores tiveram a coragem singular de rir. A criança alçou o rosto, procurando vê-los. Os risos extinguiram-se: a boca era uma chaga aberta de lado a lado por um tiro!

As mulheres eram, na maioria, repugnantes. Fisionomias ríspidas, de viragos, de olhos zanagas e maus.

Destacava-se, porém, uma. A miséria escavara-lhe a face, sem destruir a mocidade. Uma beleza olímpica ressurgia na moldura firme de 
um perfil judaico, perturbados embora os traços impecáveis pela angulosidade dos ossos apontando duramente no rosto emagrecido e pálido, aclarado de olhos grandes e negros, cheios de tristeza soberana e profunda.

Esta satisfez a ânsia contando uma história simples. Uma tragédia em meia dúzia de palavras. Um drama a bem dizer trivial, então, com o epílogo invariável de uma bala ou de um estilhaço de granada.

Postas na saleta térrea de casebre comprimido, junto ao largo, as infelizes, rodeadas pelos grupos insistentes, foram vítimas de perguntas intermináveis.

Estas deslocaram-se por fim às crianças. Procurava-se a sinceridade na ingenuidade infantil.

\section{Outra criança}

Uma delas, porém, menor de nove anos, figurinha entroncada de atleta em embrião, face acobreada e olhos escuríssimos e vivos, surpreendeu-os pelo desgarre e ardileza precoce. Respondia entre baforadas fartas de fumo de um cigarro, que sugava com a bonomia satisfeita de velho viciado. E as informações caíam, a fio, quase todas falsas, denunciando astúcias de tratante consumado. Os inquiridores registravam-nas religiosamente. Falava uma criança. Num dado momento, porém, ao entrar um soldado sobraçando a Comblain, a criança interrompeu a algaravia. Observou, convicto, entre o espanto geral, que a comblé não prestava. Era uma arma à toa, xixilada: fazia um zoadão danado, mas não tinha força. Tomou-a: manejou-a com perícia de soldado pronto; e confessou, ao cabo, que preferia a manulixe, um clavinote de talento. Deram-lhe, então, uma mannlicher. Desarticulou-lhe agilmente os fechos, como se fosse aquilo um brinco infantil predileto.

Perguntaram-lhe se havia atirado com ela, em Canudos.

Teve um sorriso de superioridade adorável:

E por que não! Pois se havia tribuzana velha!... Havera de levar pancada, como boi acuado, e ficar quarando à toa, quando a cabrada fechava o samba desautorizando as praças?!
Aquela criança era, certo, um aleijão estupendo. Mas um ensinamento. Repontava, bandido feito, à tona da luta, tendo sobre os ombros pequeninos um legado formidável de erros. Nove anos de vida em que se adensavam três séculos de barbaria.

Decididamente era indispensável que a campanha de Canudos tivesse um objetivo superior à função estúpida e bem pouco gloriosa de destruir um povoado dos sertões. Havia um inimigo mais sério a combater, em guerra mais demorada e digna. Toda aquela campanha seria um crime inútil e bárbaro, se não se aproveitassem os caminhos abertos à artilharia para uma propaganda tenaz, contínua e persistente, visando trazer para o nosso tempo e incorporar à nossa existência aqueles rudes compatriotas retardatários.

Mas, sob a pressão de dificuldades exigindo solução imediata e segura, não havia lugar para essas visões longínquas do futuro. $\mathrm{O}$ ministro da Guerra, depois de se demorar quatro dias em Queimadas removendo os últimos entraves à mobilização das forças, seguiu para Monte Santo.

\section{Na estrada de Monte Santo}

Acompanhado apenas dos estados-maiores, seu e do general Carlos Eugênio, ia atingir a base das operações, atravessando a região coalhada de feridos e aquilatando pelas fadigas que assaltaram a sua comitiva bem montada e abastecida, em caminhos livremente trafegados, as torturas que assaltariam os caminhantes que seguiam, a pé, pelas trilhas aspérrimas do sertão. Naquela travessia folgada, feita em três dias, antolhara-se-lhe em cada volta da vereda um traço lúgubre da guerra, cuja encenação a par e passo se acentuava, acompanhando a aspereza crescente da terra calcinada e estéril. O primeiro pouso em que parara, o Tanquinho, prefigurara os demais. Era o melhor e era inaturável: um sítio meio destruído, duas casas em abandono, imersas na galhada fina do alecrim-dos-tabuleiros, de onde irrompiam cereus esguios e melancólicos. O tanque que o batiza provém de um afloramento granítico originando reduzida mancha de solo impermeável sobre que jazem, estagnadas, as águas livres da sucção ávida do terreno de grés, envolvente. À sua borda, como à de todas as ipueiras marginais à estrada, sesteavam dezenas de feridos, e acampava a recovagem dos comboios. Mas isto sem a azáfama característica e ruidosa dos abarracamentos, soturnamente, silenciosamente; acúmulo entristecedor de 
homens macilentos, em grupos imóveis, paralisados na quietude de exaustão completa.

À noite, sobretudo, acesas as fogueiras rebrilhantes na superfície d’água escura, eles formavam, uns acocorados junto ao fogo e tiritando de maleitas, arrastando-se outros vagarosos e claudicantes e projetando sobre a tela unida da lagoa as sombras disformes, conjunto trágico e emocionante. Oficiais que se abeiravam sequiosos da ourela do pântano davam de chofre com espectros mal aprumados tentando fazer-lhes a continência militar: e volviam entristecidos. Dali por diante os mesmos quadros: pelos caminhos os mesmos retirantes abatidos, e, à beira dos pântanos verde-negros, recamados de algas, os mesmos agrupamentos miserandos.

Como contraste permanente, a nota superior da força e da robustez era dada, intermitentemente, pelos homens, mais tranquilos e inofensivos, irrompendo, isolados, dentre as caravanas dos guerreiros sucumbidos. No volver das inflexões da vereda, topava-se, às vezes, um vaqueiro amigo, um aliado, que se empregara nos serviços de transporte. A cavalo, entrajado de couro, sombrero largo galhardamente revirado à testa trigueira e franca; à cinta o longo facão jacaré; à destra a lança arpoada do ferrão — quedava o matuto imóvel, à orla da passagem, desviando-se, deixando livre o curso à cavalgata, numa atitude respeitosa e altiva, de valente disciplinado, muito firme dentro da sua couraça vermelho-parda feito uma armadura de bronze, figurando um campeador robusto, coberto ainda da poeira das batalhas.

A comitiva avançava e esquecia logo a imagem do sertanejo robusto - constantemente atraída pelos bandos incessantes de foragidos: soldados caminhando tardos, abordoando-se às espingardas; oficiais carregados em redes, chapéus caídos aos olhos, surdos ao tropel da cavalgata, que estrepitava a um lado, imóveis, rígidos como cadáveres; e aqui, ali, largas nódoas negras na caatinga, rastros escurentos dos incêndios, em que repontavam esteios e cumeeiras dos casebres combustos, tracejando por aqueles ermos, numa urdidura de ruínas, o cenário terrivelmente estúpido da guerra.

Em Cansanção atreguaram-se estas impressões cruéis. Houve por duas horas um remanso consolador. O vilarejo era um clã. Pertence a uma família única. O seu chefe, genuíno patriarca, congregara filhos, netos e bisnetos em ovação ruidosa ao marechal, o monarca, conforme bradava convicto, numa alacridade ingênua e sã, ao alevantar nos braços cansados de um labutar de oitenta anos o ministro surpreendido.

Esta escala foi providencial. Cansanção era um parêntese feliz naquele desolamento. E o robusto velho que o governava, surgindo blindado de uma satisfação sadia ante homens que nunca vira, e apresentando-lhes um filho de cabelos brancos e netos quase grisalhos, era, por sua vez, uma revelação. Antítese do facínora precoce de Queimadas, revelava, animadora, esta robustez miraculosa, esta nobreza orgânica completada por uma alma sem refolhos, tão característica dos matutos, quando os não derrancam o fanatismo e o crime.

Por isto o lugarejo minúsculo, uma dúzia de casas adensadas em rua de poucas braças, é o único que não desperta, nas narrativas da campanha, recordações dolorosas. Era a única zona tranquila naquela balbúrdia. Um pequeno hospital, entregue à solicitude de dois franciscanos, ali acolhia os romeiros sem forças que iam para Queimadas.

Deixando-o, os viajantes volviam logo às amarguras da trilha poenta, desesperadamente torcida em voltas infinitas, retalhando-se em desvios, orlada de choupanas estruídas e palmilhada de ponta a ponta pelas turmas sucessivas de foragidos.

\section{Palimpsestos ultrajantes}

E em toda a parte - a partir de Contendas — em cada parede branca de qualquer vivenda mais apresentável, aparecendo rara entre os casebres de taipa, se abria uma página de protestos infernais. Cada ferido, ao passar, nelas deixava, a riscos de carvão, um reflexo das agruras que o alanceavam, liberrimamente, acobertando-se no anonimato comum. A mão de ferro do exército ali se espalmara traçando em caracteres enormes o entrecho do drama; fotografando, exata, naquelas grandes placas, o facies tremendo da luta em inscrições lapidares, numa grafia bronca, onde se colhia em flagrante o sentir dos que o haviam gravado.

Sem a preocupação da forma, sem fantasias enganadoras, aqueles cronistas rudes deixavam por ali, indelével, o esboço real do maior escândalo da nossa história — mas brutalmente, ferozmente, em pasquinadas incríveis — libelos brutos, em que se casavam pornografias 
revoltantes e desesperanças fundas, sem uma frase varonil e digna. A onda escura de rancores que rolava na estrada chofrava aqueles muros, entrava pelas casas dentro, afogava as paredes até ao teto...

A comitiva, penetrando-as, repousava envolta num coro silencioso de impropérios e pragas. Versos cambeteantes, riçados de rimas duras, enfeixando torpezas incríveis na moldura de desenhos pavorosos; imprecações revoluteando pelos cantos numa coreia fantástica de letras tumultuárias, em que caíam, violentamente, pontos de admiração rígidos como estacadas de sabre; vivas! morras! saltando por toda a banda em cima de nomes ilustres, infamando-os, esbarrando-se discordes; trocadilhos ferinos; convícios desfibradores; alusões atrevidas; zombarias lôbregas de caserna...

E a empresa perdia repentinamente a feição heroica, sem brilho, sem altitude. Os narradores futuros tentariam em vão velá-la em descrições gloriosas. Teriam em cada página, indestrutíveis, aqueles palimpsestos ultrajantes.

\section{Em Monte Santo}

Os novos lutadores chegaram a Monte Santo sem o mesmo anelo de arrancar das espadas. Desenfluídos. Reanimavam-se, porém, ao entrarem na base de operações.

Despindo-se em poucos dias da aparência comum aos arraiais sertanejos, engrunhidos e estacionários, onde há cem anos não se constrói uma casa, a vila ampliara-se, tendo às ilhargas, branqueando sobre as chapadas, num bairro novo e maior que ela - 2 mil barracas, num alinhamento de avenidas longas, destacando-se distintas sobre o chão limpo e descalhoado, em seis agrupamentos, sobre que ruflavam bandeiras ondulantes, e de onde irrompiam, de instante a instante, vibrações metálicas de clarins e o toar cadente dos tambores.

Uma multidão de habitantes adventícios enchera-a, de súbito, acotovelando-se no âmbito da praça, derivando às encontroadas pelas vielas; e contemplando-os tinha-se um acervo heterogêneo em que se ombreavam todas as posições sociais. Oficiais de todas as graduações e armas; carreiros poentos das viagens longas; soldados arcando sob o equipamento; feridos e convalescentes trôpegos; mulheres maltrapilhas; fornecedores azafamados; grupos alegres de estudantes; e, num inquirir incessante, jornalistas sequiosos de notícias, davam-lhe um tom de praça concorrida em dia de parada. O marechal Bittencourt pô-la numa regulamentação rigorosa e demasiou-se no adotar medidas acordes com as exigências complexas da situação. O hospital militar tornou-se uma realidade, perfeitamente abastecido e dirigido por cirurgiões a que aliavam esforços desinteressados alguns alunos da Faculdade da Bahia. Formou-se em tudo aquilo uma disciplina correta. Por fim a questão primordial que até lá o atraíra — o serviço de transporte — se ultimou definitivamente. Diariamente quase, chegavam e volviam comboios parciais para Canudos.

Os resultados deste esforço foram imediatos. Diziam-no as notícias supervenientes da sede das operações, acordes todas no indicarem maior alento entre os sitiantes, levando-os mesmo a movimentos táticos decisivos.

É que aquele homem sem entusiasmos, que até na base das operações não despira o paletó de alpaca com que burguesmente recebia a continência das brigadas se tornara, mercê de rara dedicação e sem apisoar melindres dos que se afoitavam de perto com o inimigo, o diretor supremo da luta. A dezesseis léguas do centro desta, dirigia-a de fato, sem alardo, sem balancear alvitres estratégicos, atravessando os dias na convivência rude dos tropeiros em Monte Santo, entre os quais não raro surgia impaciente, de relógio em punho, e dava a voz de partida.

Porque cada comboio que seguia valia batalhões. Era uma batalha vencida. Punha entre os combatentes alentos de vitórias; e pouco a pouco destruía a estagnação em que se paralisara o assédio. É o que se colhia das últimas notícias.

\section{Em Canudos}

De feito, o mês de setembro principiara auspicioso.

Logo em começo, no dia 4, uma bala de carabina havia abatido no arraial um cabecilha de valor. Baqueara junto às igrejas; e o açodamento com que os habitantes se precipitaram sobre o cadáver, e o levaram, delatava-lhe o prestígio. 
A 6, sucesso de maior monta: caíram, uma após outra, as torres da igreja nova. O caso ocorrera depois de seis horas consecutivas de bombardeio. E fora inteiramente imprevisto.

Determinara-o mesmo circunstância desagradável: um engano na remessa das munições tendo levado ao arraial, ao invés de granadas, balas rasas de Krupp pouco eficazes no canhoneio, resolvera-se gastá-las logo, revezando-as, de vez, sobre as igrejas, até se acabarem.

E o resultado fora surpreendente, rememorado em duas ordens do dia entusiásticas. O exército ficara, afinal, livre das seteiras altíssimas de onde o fulminavam os sitiados, porque as duas torres assoberbando toda a linha do assédio reduziam por toda a banda os ângulos mortos das trincheiras.

Desde 18 de julho revezavam-se nos seus campanários atiradores peritos — olhos prescientes devassando tudo — a que não se subtraía o menor vulto desviado do anteparo das casas.

Os comboios, ao chegarem, dali recebiam, em cheio, no último passo, ao transporem o rio, antes da sanga em passagem coberta que os levava ao acampamento, descargas violentas.

As forças recém-vindas, a brigada auxiliar, o Batalhão Paulista e o $37^{\circ}$ de Infantaria, como vimos, do alto de suas arestas tinham recebido a primeira saudação ferocíssima do inimigo.

\section{Uma "vaia entusiástica”}

Haviam, afinal, caído. E ao vê-las baquear, uma após outra, imponentes, arrastando grandes panos de muro, desarticulando-se em grandes blocos em que vinham agarrados, tombando de borcos, atiradores atrevidos - e batendo pesadamente no chão do largo, entre nuvens de poeira da argamassa esboroada, o exército inteiro, calando a fuzilaria, atroou os ares em alaridos retumbantes.

O comandante da $1^{\mathrm{a}}$ coluna caracterizou-o bem na ordem do dia correspondente ao feito:
... prorrompendo nessa ocasião a linha de segurança e forças em apoio no acampamento entusiástica e violenta vaia na jagunçada ${ }^{1}$.

A campanha era aquilo mesmo. Do início ao termo, uma corrimaça lúgubre. Entusiástica vaia...

Como quer que seja terminara o encanto do inimigo. O arraial enorme repentinamente diminuíra; e decaíra; e se acaçapara, parecendo ainda mais afundado na depressão em que se adensava, sem mais as duas balizas brancas que o indicavam aos pegureiros - muito altas e esbeltas, arremessadas no firmamento azul, branqueando nas noites estreladas, diluindo-se misteriosamente na altura, objetivando o misticismo ingênuo e pondo junto dos céus as rezas propiciatórias dos sertanejos rudes e crendeiros...

\section{Trincheira Sete de Setembro}

Fora, além disto, o acontecimento de mau agouro. No dia subsequente sobreveio maior desastre. Desde muito entrincheirados na Fazenda Velha, algumas dezenas de guerrilheiros zombavam dos canhões do coronel Olímpio - que se emparcavam no alto num rebordo da Favela. A dois passos da artilharia e dos contingentes que a reforçavam, tinham durante mais de dois meses tolhido a dilatação do cerco por aquela banda, a despeito da tormenta de disparos que lhes estrugia a cavaleiro. Numa

\footnotetext{
1 “Quartel-General do comando do $1^{\text {a }}$ coluna - Canudos, 6 de setembro de 1897. Ordem do dia $\mathrm{n}^{\circ} 13$.

Para conhecimento das forças sob meu comando publico o seguinte:

Determinando hoje aos comandantes das bocas-de-fogo que bombardeassem as torres da igreja nova, pontos escolhidos pelo inimigo para nos tirotear com mais eficácia, fazendo-nos muitas baixas por mortes e ferimentos e resguardados de nossas pontarias, tive a satisfação de ver em seis horas consecutivas despenharem-se as torres, devido aos certeiros tiros dirigidos pelos $2^{\text {os }}$ tenentes Manuel Félix de Meneses, Frutuoso Mendes e alferes H. Duque Estrada Macedo Soares, se bem se achasse com parte de doente o primeiro.

Louvo portanto esses bravos oficiais, que ainda mais uma vez deram prova de sua perícia na direção dos canhões que comandavam, acrescendo mais ter-se o $2^{\circ}$ tenente Manuel Félix apresentado pronto, estando com parte de doente, entusiasmado com o efeito que produziu não só a este como a todo o exército, que observava com interesse o efeito da artilharia, prorrompendo nessa ocasião a linha de segurança e forças em apoio no acampamento estusástica e violenta vaia na jagunçada, e ter sido esse oficial o primeiro a iniciar o bambardeio e o último a atirar sobre a torre da direita, tendo o alferes Duque Estrada disparado o último sobre o da esquerda, conseguindo derribá-la” etc.
} 
situação dominante sobre o grosso das linhas ajustadas à orla do povoado, enfiavam-nas de ponta a ponta, contribuindo muito para as baixas diárias que as rareavam, e emparelhando-se com as torres no devassar os mais bem escolhidos parapeitos ou abrigos. Mas no dia 7, às dez horas da noite, foram, de improviso, suplantados. Animados pelos sucessos da véspera, aquele coronel, obediente ao que lhe determinara o comando da $1^{\text {a }}$ coluna, abalou com uma força composta do $27^{\circ}$, sob o comando do capitão Tito Escobar, um contingente da $4^{\mathrm{a}}$ bateria do $2^{\circ}$ Regimento, um outro do $5^{\circ}$ Regimento e uma boca de fogo. À frente e à retaguarda, seguiam ex-alunos das escolas militares. O coronel Olímpio dispôs o resto da sua pequena força em atiradores pelos dois flancos. Fê-la descer em silêncio os primeiros boléus das vertentes. Arrojou-a, por fim, num rolar de avalanche, pelo morro abaixo. Surpresos, derreando-se ao embute de trezentas baionetas repartidas em duas cargas laterais, tendo de permeio a metralha que os fulminava à queima-roupa, os jagunços mal resistiram, sendo de pronto desalojados das trincheiras de pedra, que ali tinham em torno à vivenda estruída da Fazenda Velha.

Durara cinco minutos a refrega.

Os adversários rechaçados, esparsos, perseguidos até ao cerro dos Pelados pela vanguarda, tombaram dali no rio, transpondo-o e embrenhando-se em Canudos.

A força teve apenas duas praças fora de combate.

Expugnada a posição, largo degrau sobre a vertente do morro, entre o Alto do Mário anteriormente ocupado e o Vaza-Barris, aquele coronel armou a sua barraca no lugar onde expirara seis meses antes o chefe da $3^{\text {a }}$ expedição. Empregou-se todo o resto da noite em construir, reunindo as próprias pedras das trincheiras do inimigo, forte reduto de cerca de um metro de alto, orlando toda a borda avançada do socalco. E no outro dia, cedo, a "Trincheira Sete de Setembro" sobranceava o arraial. A periferia do sítio aumentara de uns quinhentos metros para a esquerda, na direção do sul, trancando inteiramente os dois quadrantes de leste.

Ora, naquele mesmo dia, à tarde, ela se dilataria ainda mais, inflectindo a partir do ponto conquistado para o poente, até extremar a estrada do Cambaio, perto da confluência do Mucuim, abarcando toda a face do oeste.

\section{Estrada do Calumbi}

Operara-se um movimento mais sério; talvez a ação realmente estratégica da campanha. Ideara-a, planeara-a e executara-a o tenentecoronel Siqueira de Meneses. Esclarecido por informações de alguns vaqueiros leais, aquele oficial viera a saber das vantagens de uma outra estrada, a do Calumbi, ainda desconhecida, que correndo entre as do Rosário e do Cambaio, e mais curta que ambas, facilitava travessia rápida para Monte Santo, onde ia ter em traçado quase retilíneo, seguindo firmemente a linha norte-sul. E propôs-se explorá-la afrontando-se com os maiores riscos.

Realizou a empresa em três dias. Saiu no dia 4 de Canudos, à frente de quinhentos homens, que a tanto montavam, reunidos, os batalhões $22^{\circ}, 9^{\circ}$ e $34^{\circ}$, sob o imediato comando do major Lídio Porto. Varou pelo novo caminho descoberto, voltando, a 7, pelo do Cambaio, num movimento rápido, ousado, feliz, e de resultados extraordinários para o desenlace da guerra.

De feito, a nova vereda franca à translação das tropas e comboios e fechadas aos jagunços, que a trilhavam de preferência nas suas excursões para o sul, encartava de mais de um dia a jornada para Monte Santo. Era entre todas a mais bem preparada para reagir à invasão. Partia de Juá, onde bifurcava com a do Rosário, derivando à esquerda desta no rumo certo do norte, perlongando por muitos quilômetros o ribeirão das Caraíbas, ou cortando-lhe os meandros intermináveis. Avançava, invariável no rumo, tocando em pequenos sítios, até a um outro riacho de existência efêmera, o Caxomongó. Daí para a frente era uma estrada estratégica incomparável.

Alongando-se na direção de sudeste, a serrania de Calumbi flanqueiaa toda em largo trato, à direita, distante menos de trezentos metros. Um exército atravessando-a daria todo o flanco ao adversário que guarnecesse as encostas. E ao deixar esta situação gravíssima cairia em outra pior, porque o caminho, depois de galgar extensa lombada, se constringe, de repente, em angustura estreita. Nada denuncia o desfiladeiro breve e mascarado pelos esgalhos tortuosos dos pés de umburanas, que se alevantam perto. É uma muralha de mármore silicoso pouco acima do chão, à maneira de barbacã grosseira, aberta ao meio por uma diáclase, rachandoa em postigo estreito. Ali não havia trincheiras. Eram dispensáveis. As 
espingardas estendidas na crista daquele anteparo natural varreriam colunas sucessivas. E se estas vingassem transpô-lo, o que pressupunha rara felicidade contra antagonistas de tal modo abrigados e batendo-as a salvo, tombariam surpreendidas, logo aos primeiros passos, em terreno impraticável quase.

Um fato geológico vulgar nos sertões do Norte substituía, em seguida, estes acidentes, no criar idênticos empecilhos. Assim, transposta a passagem, o solo descai para o sítio da Várzea, aparentando travessia fácil mas realmente dificílima para uma tropa nas agitações do combate. Larga camada calcária derrama-se por ali, aspérrima, patenteando notável fenômeno de decomposição atmosférica. Broqueada de infinitas cavidades tangenciando-se em bordas de quinas vivas e cortantes, sarjada de sulcos fundos, de longas arestas rígidas e finas, feito lâminas de facas; erriçada de ressaltos pontiagudos; duramente rugosa em todos os pontos; escavando-se salteadamente em caldeirões largos e brunidos, patenteia impressionadoramente o influxo secular dos reagentes enérgicos, que longamente a trabalham. Corroeram-na, e perfuraram-na, e minaram-na as chuvas ácidas das tempestades, depois das secas demoradas. Ela reflete, imóvel e corroída, a agitação revolta das tormentas.

Pisando naqueles estrepes unidos e fortes, estraçoar-se-iam as mais resistentes botas e não haveria resguardos para topadas e tombos perigosíssimos. O combate seria inexequível em tal lugar, onde caminhantes tranquilos só conseguiam avançar a um de fundo, por uma trilha intermédia levando à Várzea, embaixo - ampla bacia lastrada de fragmentos de sílex e cingida de caatingas espessas. De sorte que, em ali chegando, os invasores seriam inteiramente circulados de balas. E dado que conseguissem avançar, ainda teriam adiante, transcorrido um quilômetro, o aniquilamento inevitável. A estrada desaparece caindo dentro do Rio Sargento, de leito sinuoso e fundo, e bordas nas quais rompem em grandes placas luzentes de cor azul-escura as camadas superpostas de um talcoxisto, riscadas de veios brancos de quartzo, alongando-se em certos pontos horizontalmente, quase de uma margem à outra, e dando a impressão de se passar por dentro de enorme encanamento em ruínas, conservando ainda, em vários trechos, restos da antiga abóbada desabada. Este fosso extenso que, como os demais das cercanias, não é um rio, mas um dreno transitoriamente cheio pelos enxurros que ele canaliza para o Vaza-Barris, substitui o caminho numa longura de meia légua. De uma e outra banda, apontando-lhe às margens, viam-se as trincheiras dos jagunços, pouco espaçadas, cruzando-lhe por cima os fogos, enfiando-o de esguelha ou batendo-o em cheio em todas as voltas.

Os 3 mil homens da coluna Artur Oscar não lograriam atravessá-lo. A marcha pelo Rosário fora a salvação. As antecedentes expedições, seguindo sucessivamente pelo Uauá, pelo Cambaio, por Maçacará e pelo Rosário, variando sempre na rota escolhida, tinham feito crer aos sertanejos que a última, adotada a mesma norma, tomaria pelo caminho do Calumbi, que ainda se não trilhara. $\mathrm{E}$ se tal sucedesse nem um soldado chegaria a Canudos. Um desastre maior agravaria a campanha. Tinham-se contornado por acaso, na mais completa insciência daquelas disposições formidáveis, dificuldades sérias.

O tenente-coronel Siqueira de Meneses, na sua rota admirável e feita com vantagem, porque os jagunços refluindo para o arraial haviam largado aquelas posições, foi guarnecendo os principais pontos da estrada até Juá. Daí enveredou para o Cambaio. Atravessou-lhe entrincheiramentos desguarnecidos, onde deixou, ocupando-os, uma ala do $22^{\circ}$. Passou pela lagoa do Cipó, onde alvejavam ossadas, recordando os morticínios da expedição Febrônio. Surpreendeu, aí, alguns piquetes inimigos, apresandolhes treze cargueiros. E foi surgir na confluência do Mucuim, tomando de surpresa duas trincheiras inimigas ali existentes.

O sítio ampliara-se. Rasgara-se à mobilização das forças estrada rápida e segura. O seu trecho principal desde o Rio Sargento ao sítio de Suçuarana, passando pela Várzea e Caxomongó, foi logo guarnecido pelos $33^{\circ}, 16^{\circ}$ e $28^{\circ}$ Batalhões da $2^{a}$ Brigada e uma ala do Batalhão Paulista.

Canudos tinha agora circuitando-o, do extremo norte ao sul, na Fazenda Velha, e daí para o ocidente, na ponta da estrada do Cambaio, um desmedido semicírculo de assédio.

Restavam apenas aos jagunços, no quadrante de noroeste, as veredas do Uauá e Várzea da Ema.

Prefigurava-se próximo o termo da campanha. 


\section{Capítulo II}

\section{Marcha da divisão auxiliar}

Os novos expedicionários, abalando de Monte Santo pela estrada recém-aberta, levavam um temor singularmente original: o medo cruelmente ansioso de não depararem mais um só jagunço a combater. Certo iam encontrar tudo liquidado; e sentiam-se escandalosamente traídos pelos acontecimentos.

Partira em primeiro lugar, a 13 de setembro, a brigada dos corpos policiais do Norte, e tal precedência, oriunda exclusivamente de motivos de ordem administrativa, doera fundo no ânimo dos que compunham a brigada de linha, que marcharia alguns dias mais tarde, com o general Carlos Eugênio.

\section{Medo glorioso}

É que os rebeldes decaíam tanto todos os dias, tão cheios de reveses e repelidos dos melhores pontos de apoio, e tão enleados nas malhas constritoras do cerco, que cada hora passada era para o heroísmo retardatário crudelíssimo diminuir nas probabilidades de compartir as glorificações do triunfo.

A brigada nortista fez, por isto, um avançar vertiginoso, tropeando pelos caminhos desde o primeiro alvor da antemanhã e estacando somente quando as soalheiras queimosas esgotavam a soldadesca. A de linha alcançou-a, copiando a mesma celeridade, marchando aforradamente, aguilhoada identicamente pelo anelo doido de se medir, ao menos num recontro fugitivo, com aqueles pobres adversários.

E arrojando-se pelos caminhos, os campeadores - nutridos, garbosos e sãos — lá se iam de abalada demandando a cidadela de barro, havia três meses varrida pelos canhoneios, rota pelos assaltos, devorada pelos incêndios e defendida por uma guarnição única.

Ao alcançarem o sítio da Suçuarana, seis léguas distante de Canudos, reanimavam-se. Chegavam até lá soturnamente reboando os estampidos da artilharia. Em Caxomongó, se o vento era de feição, distinguiam mesmo o crebro crepitar dos tiroteios...

\section{Caxomongó}

Entretanto nessa alacridade guerreira despontavam ainda inopinados sobressaltos. A luta sertaneja não perdera por completo o traço misterioso, que conservaria até ao fim. Avantajando-se no sertão, os sôfregos lutadores, à medida que se sentiam cada vez mais longe entre as chapadas ermas, passando pelos sítios tristonhos e destruídos - em pleno deserto - tinham entre as fileiras aguerridas irrefreáveis frêmitos de espanto. Fui testemunha de um deles.

A brigada do coronel Sotero chegara no terceiro dia de marcha, a 15 de setembro, ao sítio de Caxomongó, à entrada da zona perigosa. A escala para quem vinha de Boa Esperança, numa várzea desimpedida rodeada de pinturescas serranias, ou da Suçuarana, à borda de uma ipueira farta, era estéril e lúgubre. O terreno, de grés vermelho e grosseiro, de estratos exageradamente inclinados de $45^{\circ}$, absorvendo logo, em virtude de tal disposição, as raras chuvas que ali tombam, engravecera a dureza da caatinga.

O sítio, um pouco miserável, surge à borda do rio, e este, um valo de ribanceiras a prumo, altas de três metros, inteiramente entupido de pedras de todos os tamanhos, inteiramente seco, desaparece logo metendo-se entre colinas pouco altas e nuas.

A tropa ali chegou em plena manhã. Os dois corpos do Pará, disciplinados como os melhores de linha, e o do Amazonas, com o uniforme característico que adotara desde a Bahia: cobertos, oficiais e soldados, de grandes chapéus de palha de carnaúba, desabados, dando-lhes aparência de numeroso bando de mateiros.

Apesar da hora matinal, como encontrassem água bastante numa cacimba próxima, profundíssima e escura, lembrando a boca de uma mina, acamparam. Era a última escala. No outro dia atingiram o arraial. A paragem morta reanimou-se então, de súbito, cheia de tendas e barracas, armas em sarilhos, e a animação ruidosa de 968 combatentes. Pelas margens do rio alteavam-se ingaranas altas, cruzando-lhe as ramagens ainda 
enfolhadas sobre o leito. Armaram-se por ali fora, suspensas, à maneira de redouças oscilantes nos galhos flexíveis, dezenas de redes.

\section{E o dia derivou tranquilamente.}

\section{Nada havia a temer-se.}

Desceu a noite. Ouvia-se, muito longe, ao norte, soturno e com passado, rolando surdamente no silêncio, o bombardeio de Canudos...

$\mathrm{O}$ inimigo ali constrito não tinha mais alentos para aventurosas algaras nos caminhos. A noite, como o dia, derivaria na mais completa placidez. Mas dado que aparecessem, os jagunços viriam ao encontro de ainda não satisfeito anelo.

\section{Rebate falso}

E a tropa adormeceu cedo, em paz... para despertar toda, às dez horas da noite, num abalo único.

Detonara, no flanco esquerdo, um tiro. Uma sentinela do cordão de segurança, que se estendera em torno dos abarracamentos, lobrigara ou julgara lobrigar vulto suspeito deslizando na sombra; e disparara a espingarda. Era, certo, o inimigo anelado. Vinha como viera sobre outros expedicionários, de improviso, num arranco atrevido, e subitâneo, e célere.

Então sobre os que ansiavam tanto a medir-se com ele passou, alucinadoramente, a visão misteriosa da campanha. Avaliaram-na de perto. Dominou para logo os batalhões a hipnose de um espanto indescritível; estridularam cornetas, gritos de alarmas, brados de comandos, inquirições ansiosas; despencaram das redes, caindo sobre o lastro do rio, oficiais surpresos, pulando-lhe às tontas as bordas, esbarrando-se; caindo; precipitando-se - espadas desembainhadas, revólveres erguidos - entre as fileiras que se alinhavam num longo crepitar de estalidos de baionetas armando-se. E desencadeou-se o tumulto. Pelotões e companhias formandose ao acaso; quadrados precipitadamente feitos como esperando cargas de cavalaria; seções de armas cruzadas prontas a carregarem contra o vácuo; e entre as seções, e os pelotões, e as companhias, parte dos combatentes pervagando, correndo, em busca da formatura embaralhada...
Transcorridos minutos, os lutadores, presos de uma emoção que jamais imaginaram sentir, aguardavam o assalto. A brigada aparecia como uma longa esteira, revolta e coruscante, na onda luminosa do luar tranquilo e grande que abrangia a natureza adormecida e quieta.

E fora um rebate falso...

\section{Em busca de meia ração de glória}

Ao amanhecer extinguiram-se os temores. Volviam à impaciência heroica. Prosseguiam rápidos. Rompiam, intrêmulos, por dentro do valo sinuoso do Rio Sargento, que desbordava numa enchente repentina de fardas. Galgavam logo adiante o morro desnudo cujas vertentes opostas abruptamente caíam para o vale de Umburanas. E tinham, de surpresa, na frente e embaixo, distante dois quilômetros - Canudos...

Era um desaforo. Lá estavam as duas igrejas derruídas fronteando-se na praça lendária: a nova sem torres, alteando as paredes mestras arrombadas, fendidas de alto a baixo, um muradal cheio de entulhos; a velha em ruínas e denegrida, sem fachada, erguendo um pedaço do campanário derruído, onde o fantástico sineiro tantas vezes apelidara os fiéis para a oração e para o combate. Em volta a casaria unida. Tinham chegado a tempo. Já agora não lhes faltaria a meia ração de glória disputada. Entravam ovantes pelo acampamento, num belo aprumo de candidatos à História, procurando o pleito sanguinolento e fácil.

\section{Aspecto do acampamento}

O acampamento mudara; perdera a aparência revolta dos primeiros dias. Era como um outro arraial despontando à ilharga de Canudos. Atravessando o leito vazio do Vaza-Barris, os recém-vindos enveredavam por uma sanga flexuosa; topavam, a meio caminho à direita, entranhado em larga reentrância, vasto alpendre coberto de couro - o hospital de sangue-; e, a breve trecho, atingiam a tenda do comandante-geral.

Nesse trajeto viam-se dentro de um novo povoado.

Havia-se reconstruído o bairro conquistado. De uma e outra banda do caminho, eretas ao viés das encostas, arruadas ou acumuladas pelos vales diminutos, pintalgando, numerosas e esparsas, o tom pardo dos 
abarracamentos, sucediam-se pequenas casas de aspecto original e festivo - feitas todas de folhagens, tetos e paredes verdes de ramas de juazeiros, de forma singularmente imprópria aos habitadores. Mas eram as únicas ajustáveis ao meio. A canícula abrasante, transmudando as barracas em fornos adurentes, inspirara aquela arquitetura bucólica e primitiva.

Nada que denunciasse, ao primeiro lance de vistas, a estada de um exército. Tinha-se a impressão de chegar em vilarejo suspeito dos sertões. E encontrando-se os primitivos povoadores — homens à paisana, mal compostos, arrastando espadas e sobraçando espingardas; na maior parte cobertos de chapéus de couro com presilhas; descalços ou calçando alpercatas; e, num ou noutro ponto, mulheres maltrapilhas cosendo tranquilamente às portas ou passando arcadas sob achas de lenha, completava-se a ilusão. O estranho entrava a desconfiar que um engano na rota o havia desnorteado para o meio dos jagunços - até atingir a tenda do general, mais longe. Galgado o cerro em cujo sopé esta se erigia, chegavase, no topo, à comissão de engenharia, em casebre que não fora destruído; e, metido o olhar pelos resquícios das paredes espessadas de rachões de pedra, via-se de perto, dali cem metros, a praça das igrejas. Estava-se sobre a encosta que tinha à base as paliçadas e palancas do trecho mais perigoso do sítio, centralizado pelo $25^{\circ}$ Batalhão — a linha negra — lado por onde entrara mais fundo nos flancos do arraial o assalto de 18 de julho. Volvendo à esquerda, sob o anteparo da linha descontínua de choupanas por ali dispersas, passava-se, dados mais alguns passos, pelo quartel-general da $1^{\mathrm{a}}$ coluna. Descia-se a vertente sul seguindo por um releixo coleante, tendo à meia encosta, noutro casebre exíguo, o da segunda. Chegava-se à Repartição do Quartel-Mestre-General e acampamento do Batalhão Paulista, embaixo, numa planura arenosa, que o Vaza-Barris alaga nas enchentes. Continuando a rota, depois de atravessar o leito daquele sob o abrigo do espaldão de pedra, abarreirando-o de uma margem à outra e guarnecido pelo $26^{\circ}$, alcançava-se a tranqueira extrema do cerco, prolongada pelo $5^{\circ}$ da Bahia distendido na acanaladura funda do Rio da Providência. Dali duzentos metros, atentando para a esquerda, contemplava-se, alcandorada no alto, bojando na corcova da Fazenda Velha, à maneira de um baluarte pênsil — a trincheira Sete de Setembro.

Percorrendo desse modo a cercadura dos entrincheiramentos, os novos expedicionários tinham, nítida, a situação, traduzindo-se o exame feito num diluente do otimismo anterior. Aquele segmento do sítio era ainda escasso se o defrontavam com a amplitude do arraial. Este surpreendia-os. Afeitos às proporções exíguas das cidades sertanejas, tolhidas e minúsculas, assombrava-os aquela Babilônia de casebres, avassalando colinas.

\section{Canudos}

Canudos tinha naquela ocasião - foram uma a uma contadas depois - 5.200 vivendas; e como estas, cobertas de tetos de argila vermelha, mesmo nos pontos em que se erigiam isoladas, mal se destacavam, em relevo, no solo, acontecia que as vistas, acomodadas em princípio ao acervo de pardieiros compactos em torno da praça, se iludiam, avolumando-a desproporcionadamente. A perspectiva era empolgante. Agarrava-a o tom misterioso do lugar. Repugnava admitir-se que houvesse ali embaixo tantas vidas. A observação mais afincada, quando transitório armístico a permitia, não lograva distinguir um vulto único, a sombra fugitiva de um homem; e não se ouvia o rumor mais fugaz. Lembrava uma necrópole antiga ou então, confundidos todos aqueles tetos e paredes no mesmo esboroamento - uma cata enterroada e enorme, roída de erosões, abrindo-se em voçorocas e pregueando-se em algares.

Que o observador, porém, não avultasse demais sobre o parapeito: as balas ressaltando a súbitas, de baixo, revelavam-lhe, de pronto, a população entocada. Bastava que um disparo qualquer, a qualquer hora, atroasse o alto do morro para que dali refluísse, inevitável, o revide imediato. Porque os jagunços, se não tinham mais a iniciativa dos ataques, replicavam com 0 vigor antigo. Exauriam-se sem perder o aprumo, timbrando no disfarçar quaisquer sintomas de enfraquecimento. Compreendia-se, no entanto, que este era completo. Objetivavam-no os próprios escombros em que se entaliscavam, ocultos. Além disso, lá não estava apenas uma guarnição de valentes incorrigíveis. Havia mulheres e crianças sobre que rolavam durante três meses massas de ferros e de chamas, e elas punham muitas vezes no fragor das refregas a nota comovedora do pranto.

Dias antes um shrapnel arrojado da Favela, e que passara beirando as cimalhas da igreja nova, arrebentara dentro do casario anexo à latada das orações. E dali ascendera imediatamente uma réplica cruel perturbando os 
artilheiros do coronel Olímpio: um longo e indefinível choro; assonância dolorosíssima de clamores angustiosos, fazendo que o canhoneio cessasse à voz austera e comovida daquele comandante...

Assim, duplamente bloqueados, entre milhares de soldados e milhares de mulheres - entre lamentações e bramidos, entre lágrimas e balas - os rebeldes se renderiam de um momento para outro. Era fatal. A segurança do pleito já dera mesmo ensanchas a grandes temeridades. Um sargento do $5^{\circ}$ de Artilharia por duas vezes se aventurou, à noite, a atravessar todo o largo, penetrando no templo em ruínas, atirando lá dentro duas bombas de dinamite, que não explodiram. Um alferes do $25^{\circ}$, dias depois, copiando-lhe o arrojo, lançara fogo aos restos da igreja velha, que ardera toda.

De sorte que os lutadores vindo noviciar na pendência desigual, cientes destas coisas, recaíam na preocupação primitiva: que o inimigo in extremis tivesse ainda fôlego para lhes facultar desdobrassem o destemor e a força. A musculatura de ferro das brigadas novas ansiava a medir-se com o espernear da insurreição. Os que ali estavam havia tantos meses tinham glórias demais. Fartos, impando de triunfos e agora, mercê dos comboios diários, com a subsistência garantida, julgavam inútil despender mais vidas para que se apressasse a rendição inevitável. Quedavam numa mornidão irritante.

O acampamento, afora os intervalos, que se tornavam maiores, dos assaltos, tinha a placabilidade de uma pequena povoação bem policiada. Nada que recordasse a campanha feroz. Na sede da comissão de engenharia o general Artur Oscar, com a atração irresistível de um temperamento franco e jovial, centralizava longas palestras. Discorria-se sobre assuntos vários de todo opostos à guerra; casos felizes d'antanho, anedotas hílares, ou então alentadas discussões sobre política geral. Enquanto observadores tenazes, num invejável apego à ciência, registravam, hora por hora, pressões e temperaturas; inscreviam, invariável, um zero na nebulosidade do céu; e consultavam muito graves o higrômetro. Na farmácia militar, estudantes em férias forçadas riam ruidosamente e recitavam versos; e pelas paredes ralas de todas as choupanas ridentes, de folhagens pintalgadas de flores murchas de juazeiros, transudavam vozes e risos dos que lá dentro não tinham temores, que lhes agourentassem as horas ligeiras e tranquilas. As balas que passavam, raras, repelidas pelas cristas dos cerros em trajetórias altas, eram inofensivas. Ninguém as percebia mais. Eram, indicava-o a precisão rítmica com que estalavam ou esfuziavam nos ares, lançadas por atiradores certos, que em Canudos parecia estarem apostados a lembrar os sitiantes que o sertanejo velava. Mas não impressionavam, embora algumas, em trajetórias baixas, batessem no pano das barracas, em vergastadas rijas; como não impressionavam mais os tiroteios fortes, que ainda surgiam, às vezes, inopinadamente, à noite.

A vida normalizara-se naquela anormalidade. Despontavam peripécias extravagantes. Os soldados da linha negra, na tranqueira avançada do cerco, travavam, às vezes, noite velha, longas conversas com os jagunços. O interlocutor da nossa banda subia à berma da trincheira e, voltado para a praça, fazia ao acaso um reclamo qualquer, enunciando um nome vulgar, o primeiro que lhe acudia ao intento, com voz amiga e lhana, como se apelidasse algum velho camarada; e invariavelmente, do âmago da casaria ou, de mais perto, de dentro dos entulhos das igrejas, lhe respondiam logo, com a mesma tonalidade mansa, dolorosamente irônica. Entabulava-se o colóquio original através das sombras, num reciprocar de informações sobre tudo, do nome de batismo, ao lugar do nascimento, à família e às condições da vida. Não raro a palestra singular derivava a coisas escabrosamente jocosas e pelas linhas próximas, no escuro, ia rolando um cascalhar de risos abafados. O diálogo delongava-se até apontar a primeira divergência de opiniões. Salteavam-no, então, de lado a lado, meia dúzia de convícios ríspidos, num calão enérgico. E logo depois um ponto final - a bala...

Os soldados do $5^{\circ}$ de Polícia, malgrado o ilusório abrigo dos espaldões de terra, que os acobertavam, matavam o tempo em descantes mitigando saudades dos rincões do S. Francisco. Se a fuzilaria apertava, pulavam de arremesso aos planos de fogo; batiam-se como demônios, terrivelmente, freneticamente, disparando as carabinas; e tendo nas bocas, ressoantes, cadenciadas a estampidos, as rimas das trovas prediletas. Baqueavam, alguns, cantando; e aplacada a refrega volviam ao folguedo sertanejo, ao toar langoroso das tiranas, aos rasgados nos machetes, como se fosse aquilo uma rancharia grande de tropeiros felizes, sesteando. 
Toda a gente se adaptara à situação. O espetáculo diário da morte dera-lhe a despreocupação da vida. Os antigos lutadores andavam por fim pelo acampamento inteiro, da extrema direita à extrema esquerda, sem as primitivas cautelas. Ao chegarem aos altos expostos mal estugavam o passo ante os projetis, que lhes caíam logo à roda, batendo, ríspidos, no chão. Riam-se dos recém-vindos inexpertos, que transpunham os pontos enfiados, retransidos de sustos, correndo encolhidos, quase de cócoras, num agachamento medonhamente cômico; ou que não refreavam sobressaltos ante a bala que esfuziava perto, riscando um assovio suavíssimo nos ares, como um psiu insidiosamente acariciador da morte; ou que não tolhiam interjeições vivas ante incidentes triviais - dois, três ou quatro moribundos, diariamente removidos dos pontos avançados.

Alguns estadeavam o charlatanismo da coragem. Um esnobismo lúgubre. Fardados - vivos dos galões irradiantes ao Sol, botões das fardas rebrilhando - quedavam numa aberta qualquer livremente devassada ou aprumavam-se, longe, no cabeço desabrigado de um cerro distante dois quilômetros do arraial, para avaliarem o rigor da mira dos jagunços em alcance máximo. Calejara-os a luta. Narravam aos novos companheiros, insistindo muito nos pormenores dramáticos, as provações sofridas. Os episódios sombrios da Favela com o seu cortejo temeroso de combates e agruras. Os longos dias de privações que vitimaram os próprios oficiais, um alferes, por exemplo, morrendo embuchado, ao desjejuar com punhados de farinha após três dias de fome. As lides afanosas das caçadas aos cabritos ariscos ou das colheitas de frutos avelados nos arbustos mortos. Todos os incidentes. Todas as minúcias. E concluíam que o que restava fazer era pouco - um magro respigar no rebotalho da seara guerreira inteiramente ceifada - porque o antagonista desairado e frágil estertorava agonizando. Aquilo era agora um passatempo ruidoso, e nada mais.

A divisão auxiliar, porém, não podia ater-se a papel tão secundário: fazer trinta léguas de sertão, apenas para contemplar — espectadora inofensiva e armada dos pés à cabeça — o perdimento do arraial cedendo a pouco e pouco àquele estrangulamento vagaroso, sem a movimentação febril e convulsiva de uma batalha...

\section{Embaixada ao céu}

Mas o bloqueio, incompleto e com extenso claro ao norte, não reduzira o inimigo aos últimos recursos. Os caminhos para a Várzea da Ema e o Uauá estavam francos, subdividindo-se multívios pelas chapadas em fora, para a extensa faixa do S. Francisco, atravessando rincões de todo desconhecidos, até atingirem os insignificantes lugarejos marginais àquele rio, entre Xorroxó e Santo Antônio da Glória. Por ali chegavam pequenos fornecimentos e poderiam entrar, à vontade, novos reforços de lutadores. Porque se dirigiam precisamente nos rumos mais favoráveis, atravessando vasto trato de um território que é o núcleo onde se ligam e se confundem os fundos dos sertões de seis Estados, da Bahia ao Piauí.

Desse modo formavam aos sertanejos a melhor saída, levando-os à matriz em que se haviam gerado todos os elementos da revolta. Em último caso eram um escape à salvação. A população, trilhando-os, mal seria perseguida nas primeiras léguas, na pior alternativa. Abrigá-la-ia impérvio e indefinido - o deserto.

Não o fez, porém, embora sentisse acrescida, em torno, a força dos adversários, coincidindo-lhe com o próprio deperecimento. Haviam desaparecido os principais guerrilheiros: Pajeú, nos últimos combates de julho; o sinistro João Abade, em agosto; o ardiloso Macambira, recentemente; José Venâncio e outros. Restavam como figuras principais Pedrão, terrível defensor de Cocorobó, e Joaquim Norberto, guindado ao comando pela carência de outros melhores. Por outro lado, escasseavam os mantimentos e acentuava-se cada vez mais o desequilíbrio entre o número de combatentes válidos, continuamente diminuído e o de mulheres, crianças, velhos, aleijados e enfermos, continuamente crescente. Esta maioria imprestável tolhia o movimento dos primeiros e reduzia os recursos. Podia fugir, escoar-se a pouco e pouco em bandos diminutos pelas veredas que restavam, deixando aqueles desafogados e forrando-se ao último sacrifício. Não o quis. De modo próprio todos os seres frágeis e abatidos, certos da própria desvalia, se devotavam a quase completo jejum, em prol dos que os defendiam. Não os deixaram. 
A vida no arraial tornou-se então atroz. Revelaram-na depois a miséria, o abatimento completo e a espantosa magreza de seiscentas prisioneiras. Dias de angústias indescritíveis foram suportados diante das derradeiras portas abertas para a liberdade e para a vida. E permaneceriam para todo o sempre inexplicáveis, se, mais tarde, os mesmos que os atravessaram não revelassem a origem daquele estoicismo admirável. É simples.

Falecera a 22 de agosto Antônio Conselheiro.

Ao ver tombarem as igrejas, arrombado o santuário, santos feitos em estilhas, altares caídos, relíquias sacudidas no encaliçamento das paredes e - alucinadora visão! — o Bom Jesus repentinamente a apear-se do altarmor, baqueando sinistramente em terra, despedaçado por uma granada, o seu organismo combalido dobrou-se ferido de emoções violentas. Começou a morrer. Requintou na abstinência costumeira, levando-a a absoluto jejum. E imobilizou-se certo dia, de bruços, a fronte colada à terra, dentro do templo em ruínas.

Ali o encontrou numa manhã Antônio Beatinho.

Estava rígido e frio, tendo aconchegado do peito um crucifixo de prata.

Ora, este acontecimento - capital na história da campanha - e de que parecia dever decorrer o seu termo imediato, contra o que era de esperar aviventou a insurreição. É que, gizada talvez pelo espírito astucioso de algum cabecilha, que prefigurara as consequências desastrosas do fato, ou, o que se pode também acreditar, nascida espontaneamente da hipnose coletiva, logo que a beataria impressionada notou a falta do apóstolo, embora este nos últimos tempos aparecesse raras vezes — se divulgou extraordinária notícia.

Relataram-na depois, ingenuamente, os vencidos:

Antônio Conselheiro seguira em viagem para o céu. Ao ver mortos os seus principais ajudantes e maior o número de soldados, resolvera dirigir-se diretamente à Providência. O fantástico embaixador estava àquela hora junto de Deus. Deixara tudo prevenido. Assim é que os soldados, ainda quando caíssem nas maiores aperturas, não podiam sair do lugar em que se achavam. Nem mesmo para se irem embora, como das outras vezes. Estavam chumbados às trincheiras. Fazia-se mister que ali permanecessem para a expiação suprema, no próprio local dos seus crimes. Porque o profeta volveria em breve, entre milhões de arcanjos, descendo - gládios flamívomos coruscando na altura - numa revoada olímpica, caindo sobre os sitiantes, fulminando-os e começando o Dia do Juízo...

Desoprimiram-se todas as almas; dispuseram-se os crentes para os maiores tratos daquela penitência, que os salvava; e nenhum deles notou que logo depois, sob pretextos vários, alguns incrédulos, e entre eles VilaNova, abandonavam a povoação, tomando por ignoradas trilhas.

Saíam ainda em tempo. Eram os últimos que escapavam, porque no dia 24 a situação mudou.

\section{Complemento do assédio}

Logo ao alvorecer, enquanto a esquerda da linha e os canhões da Favela iniciavam renhido ataque, atraindo para aquele lado a atenção do inimigo, o tenente-coronel Siqueira de Meneses, seguido pelos $24^{\circ}$, $38^{\circ}$ e $32^{\circ}$ Batalhões de linha, comandados pelo major Henrique de Magalhães, capitão Afonso Pinto de Oliveira e tenente Joaquim Potengi; o do Amazonas; a ala direita do de S. Paulo, guiada pelo major José Pedro de Oliveira; e um contingente de cavalaria ao mando do alferes Pires de Almeida - abalara o segmento ainda desguarnecido do assédio, assaltando os pequenos contingentes que o guarneciam dentro das últimas vivendas, que se derramavam, esparsas, por aquela banda.

Os jagunços não contavam que fossem até lá. Era o ponto de Canudos diametralmente oposto à Fazenda Velha e mais distante da primitiva frente do assalto.

Via-se ali um subúrbio novo, as Casas Vermelhas, ereto depois do fracasso da $3^{\text {a }}$ expedição, e nele edificações mais corretas, cobertas, algumas de telhas. Não estava guarnecido convenientemente. Faltavam-lhe as trincheiras-abrigos, que abrolhavam tão numerosas noutros pontos, e, circunstância na emergência desastrosa para os rebeldes, todas as vivendas pelo fato de serem as mais remotas se atestavam de mulheres e crianças.

A força tendo à vanguarda o $24^{\circ}$, marchando pelo leito do rio, caiulhes em cima e varejou-as em minutos. Como em geral acontecia, os 
guerrilheiros viram-se tolhidos na balbúrdia do mulherio medroso. Entretanto não cederam desde logo a posição. Recuaram, resistindo; e acompanhando-os os soldados foram embrenhando-se nas vielas.

Tomando a ofensiva, reeditavam episódios inevitáveis. Enfiavam as espingardas pelos tabiques de taipa, disparando-as, a esmo, para dentro; arrombavam-nos depois a coronhadas; e sobre a acendalha de trapos e móveis miseráveis atiravam fósforos acesos. Os incêndios deflagravam, abrindo-lhes caminho. Adiante recuava o sertanejo, recuando pelos cômodos escusos. Aqui, ali, destacadamente, uma resistência estupenda de um ou outro, jogando alto a vida. Um deles, abraçado pela esposa e a filha, no momento em que a porta da choupana se escancarou, estrondada em lascas, atirou-as rudemente de si: assomou de um salto ao limiar e abateu, num revide terrível, o primeiro agressor que deparou, um alferes, Pedro Simões Pinto, do $24^{\circ}$. Baqueou logo, circulado pelos soldados, a cutiladas. E ao expirar teve uma frase lúgubre: “Ao menos matei um...”.

Outro distraiu os soldados. Episódio truanesco e medonho: num recanto da saleta invadida, caído de banda, sem alento sequer para sentarse, adelgaçado de magreza extrema, um curiboca velho, meio desnudo, revestido de esparadrapos, forcejava por disparar uma lazarina antiga. Sem forças para aperrá-la, levantava-a a custo. Deixava-a logo descair nos braços frouxos, desesperado, refegada a face ossuda, num esgar de cólera impotente. As praças rodearam-no um momento; e seguiram num coro estrepitoso de risadas.

Mas este resistir a todo o transe, em que entravam os próprios moribundos, cortou-lhes, afinal, o passo. Em pouco tempo tiveram treze baixas. Além disto o adversário recuava, mas não fugia. Ficava na frente, a dois passos, na mesma vivenda, no cômodo próximo, separado por alguns centímetros de taipa. Estacaram. Para não perderem o avançamento feito abarreiraram, com os móveis e destroços das casas, toda a frente da posição. Era o processo usual e obrigatório.

Defronte não havia terreno neutro. O jagunço ficava colado indomável — na escarpa oposta do parapeito, vigilante, tenteando a pontaria.

\section{Cenário de tragédia}

Esta refrega, atroando ao norte, ecoava no acampamento, alarmandoo. Atestadas de curiosos, todas as casinhas adjacentes à comissão de engenharia formavam a plateia enorme para a contemplação do drama. Assestavam-se binóculos em todos os rasgões das paredes. Aplaudia-se. Pateava-se. Estrugiam bravos. A cena — real, concreta, iniludível aparecia-lhes aos olhos como se fora uma ficção estupenda, naquele palco revolto, no resplendor sinistro de uma gambiarra de incêndios. Estes progrediam constrangidos, ao arrepio do sopro do nordeste, esgarçando-lhe a fumarada amarelenta, ou girando-a em rebojos largos em que fulguravam e se diluíam listrões fugazes de labaredas. Era o sombreado do quadro, abrangendo-o de extremo a extremo e velando-o de todo, às vezes, como o telão descido sobre um ato de tragédia.

Nesses intervalos desaparecia o arraial. Desaparecia inteiramente a casaria. Diante dos espectadores estendia-se, lisa e pardacenta, a imprimidura, sem relevos, do fumo. Recortava-a, rubro e sem brilhos uma chapa circular em brasa - um Sol bruxuleante, de eclipse. Rompia-a, porém, de súbito, uma lufada rija. Pelo rasgão enorme, de alto a baixo aberto, divisava-se uma nesga do arraial — bandos estonteados de mulheres e crianças correndo para o sul, em tumulto, indistintos entre as folhagens secas das latadas. As baterias da Favela batiam-nos de frente. Os grupos miserandos, entre dois fogos, fustigados pela fuzilaria, repelidos pelo canhoneio, desapareciam, por fim, entaliscados nos escombros, ao fundo do santuário. Ou escondiam-nos outra vez, promanando da combustão lenta e inextinguível e rolando vagarosamente sobre os tetos, os novelos de fumo, compactos, em cúmulos, alongando-se pelo solo, empolando-se na altura, num tardo ondular de grandes vagas silenciosas, adensando-se e desfazendo-se à feição dos ventos; chofrando a frontaria truncada da igreja nova, deixando lobrigar-se num pedaço de muramento esboroado, e encobrindo-o logo; dissolvendo-se adiante sobre um trecho deserto do rio; espraiando-se mais longe, delidos, pelo topo dos outeiros...

As vistas curiosas dos que pelo próprio afastamento não compartiam a peleja coavam-se naquele sendal de brumas. E quando estas se adunavam impenetráveis, em toda a cercadura de camarotes grosseiros do monstruoso anfiteatro explodiam irreprimíveis clamores de 
contrariedades e desapontamentos de espectadores frenéticos, agitando os binóculos inúteis, procurando adivinhar o enredo inopinadamente encoberto.

Porque a ação se delongava. Delongava-se anormal, sem o intermitir das descargas intervaladas, o tiroteio cerrado e vivo, crepitando num estrepitar estrídulo de tabocas estourando nos taquarais em fogo. De sorte que por vezes pairava no ânimo dos que o escutavam, ansiosos, o pensamento de uma surtida feliz dos sertanejos, saindo pelas tranqueiras rotas ao norte. Os ecos dos estampidos, variando de rumos, torcidos em ricochete pelos flancos das colinas, subindo de intensidade no nevoeiro compacto, desviavam-se. Estalavam-lhes perto, à direita e à retaguarda, dando a ilusão de um ataque do inimigo escapo e precipitando-se, em tropel, num revide repentino. Trocavam-se ordens precípites. Formavam-se os corpos de reserva. Cruzavam-se inquirições comovidas...

Ouvia-se, porém, longínquo, um ressoar de brados e vivas. Corria-se aos mirantes acasamatados. Retomavam-se os binóculos. Uma rajada corria, em sulco largo e límpido, pela cerração dentro, talhando-a de meio a meio, e desvendando de novo o cenário.

Era um desafogo. Vozeavam aclamações e aplausos. Os jagunços recuavam.

Por fim se viu, estirando-se até ao caminho do Cambaio, uma linha de bandeirolas vermelhas.

Estava bloqueado Canudos.

A nova chegou em pouco ao acampamento de onde largaram, à espora fita, correios para Monte Santo, levando-a, para que de lá o telégrafo a espalhasse no país inteiro.

Circuitava agora toda a periferia do povoado uma linha interrompida de tranqueiras, nos intervalos das quais não havia escoar-se mais um único habitante: a leste, o centro do acampamento, à retaguarda da linha negra, centralizada pela $3^{\text {a }}$ Brigada; ao norte, as posições recémexpugnadas, alongando-se guarnecidas sucessivamente pelo $31^{\circ}$, ala esquerda do $24^{\circ}, 38^{\circ}$, ala direita do Batalhão Paulista e o $32^{\circ}$, de Infantaria, cortando as estradas do Uauá e a Várzea da Ema; em todo o quadrante de noroeste, guarnições espaçadas, ladeando o redente artilhado no extremo da vereda do Cambaio; a Favela e o baluarte dominante da Sete de Setembro, ao sul. efetivo.

Ainda que em fragmentos, traçara-se a curva fechada do assédio real, 